УДК 811.161.2’373.611

Р. В. Познанський

\title{
РЕАЛІЗАЦІЯ ТЕМПОРАЛЬНОЇ ВАЛЕНТНОСТІ ДІЕСЛОВАМИ СЕМАНТИЧНОГО ПОЛЯ «АГРАРНЕ ВИРОБНИЦТВО (РОСЛИННИЦТВО)»
}

Познанський P. В. Реалізація темпоральної валентності дієсловами семантичного поля «аграрне виробництво (рослинництво)».

У статті здійснюється аналіз темпоральної валентності дієслів семантичного поля «аграрне виробництво (рослинництво)», яка реалізується у семантичних позиціях «почати виконувати дію», «виконувати дію якийсь час», «закінчувати виконувати дію». Пояснюються причини, які впливають на маніфестацію темпоральних модифікацій в межах аналізованого нами семантичного поля.

Ключові слова: темпоральна валентність, дериват, семантичне поле, темпоральні модифікації.

Познанский $\quad$ P. В. Реализация темпоральной валентности глаголами семантического поля «аграрное производство (растениеводство)».

В статье проводится анализ темпоральной валентности глаголов семантического поля «аграрное производство (растениеводство)», которая реализуется в семантических позициях «начать выполнять действие», «выполнять действие некоторое время», «заканчивать выполнять действие». Объясняются причины, которые влияют на манифестацию темпоральных модификаций в рамках рассматриваемого нами семантического поля.

Ключевые слова: темпоральная валентность, дериват, семантическое поле, темпоральные модификации.

Poznanskyy R. V. Realization of Temporal Valance by Verbs of Semantic Field "Agricultural Production (Crop Production)".

The analysis of temporal valence of verbs of semantic field "agricultural production (crop production)", which is realized in semantic positions "to begin to perform an action", "to perform an action for some time", "to finish performing an action", is done in the article. The reasons which affect the manifestation of temporal modifications within the analyzed semantic field are also explained.

Key words: temporal valence, derivative, semantic field, temporal modifications. 
Поняттю дієслівної валентності присвячено чимало праць у вітчизняному та зарубіжному мовознавстві $[3 ; 5 ; 6 ; 7 ; 8]$, приділяється увага цій проблемі й у роботах, зосереджених на дослідженні віддієслівного словотворення [4, с. 12-15]. Однак аналіз реалізації саме темпоральної валентності дієсловами семантичного поля «аграрне виробництво (рослинництво)» ще не ставав предметом спеціального наукового дослідження, що зумовлює актуальність і новизну пропонованої теми.

У нашій статті ставиться завдання виявити та проаналізувати темпоральні валентні можливості дієслів семантичного поля «аграрне виробництво (рослинництво)».

У межах семантичного поля «аграрне виробництво (рослинництво)» виділяємо такі лексико-семантичні групи (мікрополя) дієслів [9, с. 8]:

1. Дієслова на позначення процесів обробітку грунту.

2. Дієслова на позначення процесів обробітку насіння (дієслова насінництва).

3. Дієслова на позначення процесів садіння чи сіяння насіння.

4. Дієслова на позначення процесів догляду за рослинами під час їхнього росту та дозрівання.

5. Дісслова на позначення процесів збирання урожаю.

6. Дієслова на позначення процесів підготовки реманенту.

7. Дієслова на позначення процесів завдання шкоди аграрному господарству.

8. Дієслова на позначення процесів, які безпосередньо не здійснюються людиною, зокрема:

a) пов'язаних із ростом та дозріванням рослин;

б) пов'язаних із знищенням, загибеллю рослин.

9. Дієслова загальної аграрної семантики.

Дієсловам більшості зазначених мікрополів властива темпоральна валентність, яка реалізується у семантичних позиціях «почати виконувати дію», «виконувати дію якийсь час», «закінчувати виконувати дію».

Словотвірне значення «почати виконувати дію» притаманне поодиноким дериватам, хоч фазі початку будь-якої роботи в полі, у саду, у лісі і т. ін. здавна в українській традиції приділяли чимало уваги. Однак такий початок дії зазвичай номінується аналітично за допомогою дієслівмаркерів почати, розпочати, починати, розпочинати та ін. (почати збір урожаю, починати орати, почати косити, розпочати сапати, почати сіяти, почати зривати фрукти і под.). Загалом дієслова зі словотвірним значенням початку виконання дії мотивуються вербативами такої ○ Р. В. Познанський, 2015. 
семантики, як-от: дієслова на позначення процесів збирання урожаю заграбувати, загрібати, загребти (у 6 знач. 'почати розгрібати, розривати що-небудь сипке'); щоправда, у значенні початку виконання дії дієслова загрібати та загребти частіше використовуються поза номінацією сільськогосподарських процесів, називаючи початок процесу греблі веслами; дієслова на позначення процесів, які безпосередньо не здійснюються людиною, а саме: а) пов'язаних із ростом та дозріванням рослин: забубнявіти, забрунькувати, забуяти, загалузитися, заколоситися, зажовтіти, зацвітати та ін.; б) пов'язаних із знищенням, загибеллю рослин: зав'янути, зав'яти, забур'яніти, замокати, замокнути.

Назване словотвірне значення фіксуємо й у дериватах, мотивованих дієсловами загальної семантики, зокрема завесновувати.

Відсутність дериватів зі словотвірним значенням «почати виконувати дію» від більшості дієслів семантичного поля «аграрне виробництво (рослинництво)» зумовлене, на нашу думку, кількома причинами. Так, за семантикою дієслова окремих мікрополів позначають процеси, нетривалі в часі, які, отже, не мають чітко виокремлених фаз початку чи кінця. До таких дієслів відносимо, зокрема, дієслова шостого мікрополя, які позначають процеси підготовки реманенту: вимантачити (гострити мантачкою), клепати (косу), гострити (плуг, сапу), набити (cany, лопату на держак) тощо. 3 іншого боку, мотивовані «аграрними» дієсловами деривати 3 префіксом за-, який в українській мові відповідає за «починальність», можуть мати абсолютно інші словотвірні значення, пор.: загребти, завеснувати (довести дію до результату), загортати (садити коренеплоди, наприклад, картоплю) тощо.

Більше того, у структурі наведених дериватів, окрім семи починальності, актуалізуються й інші семи, передусім вичерпності дії, поширення дії на всю територію. Пор., наприклад: заколоситися 'почати колоситися, викидати колос. // Вкритися колоссям (про землю, ниву і т. ін.)'

У семантичній позиції «закінчувати виконувати дію» маніфестовані похідні від дієслів таких мікрополів:

1. Дісслова на позначення процесів обробітку грунту: доборознити, доборонувати, добукерувати, доволочити, додернувати, домеліорувати, доорати, доплужсти, доралити, дочизелювати, досапати, докопати, докорчувати, викорчувати, культивувати та ін.

2. Дієслова на позначення процесів обробітку насіння (дієслова насінництва): довіяти, долузати, долущити, дорещетувати, досортувати, досушити, домолотити.

3. Дієслова на позначення процесів садіння чи сіяння насіння: $-177-$ () Р. В. Познанський, 2015. 
досадити, досіяти.

4. Дієслова на позначення процесів догляду за рослинами під час їхнього росту та дозрівання: добукетувати, довалашати, завершкувати, докільиювати, досапати, дотичити, дощепити та ін.

5. Дієслова на позначення процесів збирання урожаю: дозбирати, дозгрібати (сіно), докосити, завершити (стіг), вивершити, дожати, домолотити, допрєтати, докопати, довалкувати та ін.

6. Дієслова на позначення процесів підготовки реманенту: доклепати (косу), догострити (плуг, сапу).

7. Дієслова на позначення процесів завдання шкоди аграрному господарству: довимикувати, довипалювати, довиривати, довирубувати, довисмикувати, доломити, дотолочити, дотоптати, домикати, дозривати, довисушувати, докорчувати та ін.

8. Дієслова на позначення процесів, які безпосередньо не здійснюються людиною: а) пов'язаних із ростом та дозріванням рослин: дозріти, достигнути, розм. вимахати, доцвісти, діал. визернюватиси 'дозріти, достигнути (про кукурудзу)'; б) пов'язаних із знищенням, загибеллю рослин: догнити, домерзнути, дов'янути, відзеленіти, відквітнути, відв'янути.

Серед дієслів загальної семантики також є твірні аналізованих дериватів: довеснувати, повеснувати, завеснувати, діал. укутатися (у 2 знач.) 'закінчити польові роботи', докінчити, доробити.

Як бачимо, більшість дериватів утворено за допомогою префікса до-, хоч фіксуємо й похідні дієслова іншої словотвірної структури, наприклад, серед діалектних лексем: укутатися, повеснувати, визернюватися, завершити (стіг), вивершити, вив'язати тощо. Префікс до- $є$ типовим виразником семантики завершальності в українській мові, «фінітивна сема якого невіддільна від представленої дієсловом семи, що конкретизується як результат дії» [1, с. 176]. При цьому в похідних дієсловах, які утворені за допомогою інших формантів, можуть 3'являтися додаткові прирощені значення. Наприклад, девербативи доорати та відорати мають лексичне значення «закінчити орати», однак девербатив із префіксом від- передає семантику фатальної остаточної завершеності дії, яка більше не буде повторюватися у певний проміжок часу. Така семантика конкретизується у синтагмах на сьогодні вже відорав, відорав уже своє поле, він своє відорав тощо. Натомість такої фатальної завершеності не спостерігаємо в типових девербативах із префіксом до-. Стосовно аналізованого прикладу, то семантика завершеності дії в дериваті доорати проектується не в темпоральну площину, а на об'єкт дії, адже можна доорати тут і відразу

() Р. В. Познанський, 2015.

$-178-$ 
ж доорати де-інде. Загалом розмаїття словотворчих засобів вираження семантичної позиції «закінчувати виконувати дію» зумовлене діалектним словотворенням, де завершальна семантика може передаватися префіксами по- (повеснувати - 'закінчити веснувати, закінчити весняні сільськогосподарські роботи'), ви- (визернюватися 'дозріти, достигнути (про кукурудзу)', вивершити 'завершити копицю чи стіг'), за- (завершити (стіг), $y$ - (укутатися 'завершити поратися по господарству; завершити роботи в полі').

Зауважимо також, що семантика завершальності притаманна похідним, мотивованим дієсловами всіх груп семантичного поля «аграрне виробництво (рослинництво)».

С3 «виконувати дію якийсь час» реалізували похідні всіх груп дієслів зі значенням: 1) дієслова на позначення процесів обробітку грунту: поборознувати, поборонувати, побукерувати, погноїти, поволочити, подернувати, подискувати, поорати, попаювати, поралити, порихлити, почизелювати, посапати, покопати, покорчувати та ін.; 2) дісслова на позначення процесів обробітку насіння (дієслова насінництва): полузати, посортувати, посушити, помолотити; 3) дісслова на позначення процесів садіння чи сіяння насіння: повисаджувати, повисівати; 4) дієслова на позначення процесів догляду за рослинами під час їхнього росту та дозрівання: пополоти, прополоти, пополивати, посапати, потичити, позагрібати, побукетувати, повалашати, повершкувати, покільцювати, пооббризкати, пообв'язувати, попідгортати, попідливати, попросапувати, пощепити та ін.; 5) дієслова на позначення процесів збирання урожаю: позгрібати (сіно), покосити, повалкувати, пожати, повикопувати (картоплю), покосити, пообтрушувати, помолотити, покопати та ін.; 6) дієслова на позначення процесів підготовки реманенту: поклепати (косу), погострити (плуг, сапу); 7) дієслова на позначення процесів завдання шкоди аграрному господарству: повикоріняти, повипалювати, повиривати, повирубувати, повисмикувати, повищипувати, потолочити, потоптати, позривати, позрізати, повисушувати, покорчувати та ін.; 8) дієслова на позначення процесів, які безпосередньо не здійснюються людиною: а) пов'язаних із ростом та дозріванням рослин: побубнявіти, поколоситися, покущитися, пополовіти, посходити, поцвісти, пожовтіти, пожовкнути та ін.; б) пов'язаних із знищенням, загибеллю рослин: побур'яніти, повигорати, повисихати, повідмерзати, пов'янути, погнити, подичавіти, попріти, пожовтіти та ін.; 9) дієслова загальної семантики: пообробляти, політувати, повеснувати.

Серед похідних, представлених у С3 «виконувати дію якийсь час», 
виділяємо дві групи лексем, які різняться семантикою. До першої групи належать девербативи 3 формантом по-, які позначають неозначенотривалу дію, означувані такими дієсловами процеси можуть супроводжуватись обставинами на зразок трохи, недовго [2, с. 205]: трохи посапати, недовго поорати тощо. Дієслова другої групи, до морфемного складу яких входить префікс про-, передають «значення певної тривалості», «дія, означувана цими дієсловами, може тривати годину, день, тиждень і т. ін., тобто вона введена в певні часові рамки» [1, с. 205]. Наприклад: прогребти иілий день, проорати до обіду тощо.

Деривати із префіксом no-, окрім значення тривалості дії, актуалізують також сему всеохопності об'єкта, наприклад: потичити (потичити якийсь час - потичити все поле), погноїти (погноїти якийсь час- погноїти все поле) та ін.

Загалом від аналізованих твірних зафіксовано невелику кількість дериватів із темпоральними модифікаціями, що пояснюється водночас також тим, що в українській мові такі модифікації доволі часто передаються аналітично за допомогою слів почати та закінчити (завершити), які поєднуються в підрядні словосполучення 3 дієсловами семантичного поля «аграрне виробництво (рослинництво)»: почати сіяти, завершити садити, почати поливати, закінчити сапати тощо. Пропонована стаття доповнює й розширює здійснені дослідження темпоральної валентності. Перспективи подальшого дослідження вбачаємо в аналізі реалізації темпоральних модифікацій дієсловами інших лексико-семантичних груп.

\section{Література}

1. Безпояско О. К. Морфеміка української мови / О. К. Безпояско, К. Г. Городенська. - К. : Наукова думка, 1987. - 389 с.

2. Безпояско О. К. Граматика української мови / О. К. Безпояско, К. Г. Городенська, В. М. Русанівський. - К. : Либідь, 1993. - 394 с.

3. Вихованець І. Частини мови в семантико-граматичному аспекті / І. Вихованець. - К. : Наукова думка, 1988. - 256 с.

4. Джочка І. Ф. Дериваційний потенціал дієслів конкретної фізичної дії 3 семантикою створення об'єкта : дис. ... канд. філол. наук / І. Ф. Джочка. - ІваноФранківськ, 2003. - 194 с.

5. Загнітко А. П. Структура та ієрархія валентних значень дієслова / А. П. Загнітко. - К. : НМК ВО, 1990. -64 с.

6. Кацнельсон С. Д. Типология языка и речевое мышление / С. Д. Кацнельсон. Л. : Наука, 1972. -216 с.

7. Кровицька О. Назви осіб в українській мовній традиції XVI-XVII ст. Семантика і словотвір / О. Кровицька. - Львів : НАН України, Ін-т українознавства ім. І. Крип'якевича, 2002. -284 с.

() Р. В. Познанський, 2015. 
8. Морозова Т. С. Синтаксические свойства глагола и его слово-образовательный потенциал / Т. С. Морозова // Проблемы структурной лингвистики 1982. - М. : Наука, 1984. - C. 88.

9. Познанський Р. В. Словотворча спроможність дієслів семантичного поля «аграрне виробництво (рослинництво) : автореф. дис. ... канд. філол. наук / Р. В. Познанський. Івано-Франківськ, 2014. - 20 с.

Стаття надійшла до редакиії 12.09.2015 p. 